\title{
BÖTE Bölümlerine 2017 Yılında Yerleşen Öğrencilerin Tercihlerini Etkileyen Faktörler”
}

\author{
Çiğdem Uz Bilgin $^{* * 1}$, Melike Kavuk Kalender ${ }^{2}$, M. Betül Yılmaz ${ }^{3}$, Feza Orhan ${ }^{4}$, Mukaddes Erdem ${ }^{5}$ ve Soner \\ Yildırım ${ }^{6}$
}

Öz

Anahtar Sözcükler

2017 ÖSYS sonuçlarına göre Türkiye'deki Bilgisayar ve Öğretim Teknolojileri Eğitimi (BÖTE) bölümlerinin yedisine hiç öğrenci yerleşmemiş, 38'ine ise dokuz ve/veya daha az sayıda öğrenci yerleşmiştir. Bu bölümlerden sadece dördü kontenjanını tam doldururken, \% 22'si ise kapasitesinin \% 20 - \%60 arasını doldurmuşlardır. $\mathrm{Bu}$ durumu etkileyen unsurları ortaya çıkarmak üzere, yerleşen öğrencilerin BÖTE bölümlerini tercihlerini etkileyen sebeplerin belirlenmesi gerektiği düsünülmüstür. Bu doğrultuda bu araştırmada, kontenjanını tam dolduran ile \% 20 - \% 60 bandında dolduran BÖTE'lerdeki öğrencilerin tercihlerinde üniversite ve bölümlerle ilgili özelliklerin etkisi incelenmiştir. Araştırmada, kontenjanını \%20 ve üstü oranlarda doldurmus 12 farklı BÖTE bölümündeki 290 öğrenciden tarama yöntemi ile veri toplanmıştır. Bu amaçla geliştirilen iki ölçeğin faktör yapıları belirlenmiş, geçerlik ve güvenirlik çalışması yapılmıștır. Üniversite ile ilgili özelliklerin tercihlere etkisi ölçeği 14 madde ve dört boyuttan (tavsiye, konum, olanaklar, nam), Bölüm ile ilgili özelliklerin tercihlere etkisi ölçeği ise 9 madde ve iki boyuttan (nitelik, tavsiye) oluşmaktadır. Yapılan analizler üniversitenin sunduğu olanaklar ve bölümün niteliği boyutlarının tercih belirlemede etkisinin kontenjanı tam dolduran BÖTE'ler lehine; üniversitenin konumu boyutunun ise kontenjanını tam doldurmayan BÖTE'ler lehine istatistiksel olarak anlamlı fark yarattığını göstermiștir. Öğrencilerin tercih nedenlerine ilișkin görüșlerinin puan ortalamaları; üniversitenin bütününe yönelik özellikler açısından 6 üzerinden 3.63, bölüm özellikleri açısından ise 2.72 olarak hesaplanmıștır.

DOI: $10.12984 /$ egeefd.491627

\section{The Factors Affecting the University Preferences of Students Who were Placed in CEIT Departments in 2017*}

Abstract

According to the results of 2017 Student Selection and Placement Exam, referred as SSPE, none of the students were placed in 7 of the Computer Education and Instructional Technologies (CEIT) departments and nine or less number of students were placed in the remaining 38 of them. While four of the departments have fully filled their quotas, $22 \%$ of them have filled their capacity between $20 \%$ and $60 \%$. In this respect, there is a need to conduct research to determine reasons that affect students' preferences of selecting CEIT departments. In the present study, it is aimed to explore the university and department-related features that affect the preferences of students from CEIT departments that fully filled their quota or between $20 \%-60 \%$ of their capacity. The data were gathered by survey research method from 290 students who were enrolled in 12 different CEIT departments, which filled their quota with $20 \%$ or more. In this respect, two different scales were developed as data collection tools, their factors were determined, and validity-reliability analyses were performed. The first scale the impact of university-related features on preferences was composed of 14 items and four factors (advice, location, opportunity, and reputation), the impact of department-related features on preferences scale was composed of nine items and two factors (quality, advice). Statistical analyses showed that the impact of university opportunities and department quality factors on determining preference revealed significant difference in the favor of CEITS which fully filled their quota, the factor of university location revealed significant difference in the favor of CEITS which did not fully fill their quota. The mean scores of the opinions of the students on the reasons of preference was calculated as 3.63 out of 6 in terms of university-related features and 2.72 in terms of department-related features.
Keywords

SSPE

CEIT

University preference

Article Info

Received

December 03, 2018

Accepted

July 08, 2019

Article Type

Research Paper

Atıf: Uz Bilgin, Ç., Kavuk Kalender, M., Yılmaz, M. B., Orhan, F., Erdem, M. ve Yıldırım S. (2019). BÖTE bölümlerine 2017 yılında yerleşen öğrencilerin tercihlerini etkileyen faktörler. Ege Eğitim Dergisi, 20(1), 278-290. doi: 10.12984/egeefd.491627

\footnotetext{
* Bu çalışma, 02-04 Mayıs 2018 tarihleri arasında İzmir'de düzenlenen 12. Uluslararası Bilgisayar ve Öğretim Teknolojileri Sempozyumunda 04, 2018]

${ }^{* *}$ Sorumlu Yazar/Corresponding Author

1 (ㄷ) Yıldız Teknik Üniversitesi, Eğitim Fakültesi, BÖTE Bölümü, Türkiye, uzcigdem@gmail.com

2 단 Yıldız Teknik Üniversitesi, Eğitim Fakültesi, BÖTE Bölümü, İstanbul, Türkiye, melikekavuk@ gmail.com

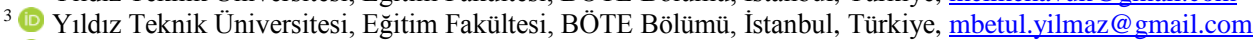

4 (1) Yıldız Teknik Üniversitesi, Eğitim Fakültesi, BÖTE Bölümü, İstanbul/ Türkiye, feza.orhan@ gmail.com

5 (ㄷ) Hacettepe Üniversitesi, Eğitim Fakültesi, BÖTE Bölümü, Ankara, Türkiye, erdemm@ hacettepe.edu.tr

${ }^{6}$ ○ Orta Doğu Teknik Üniversitesi, Eğitim Fakültesi, BÖTE Bölümü, Ankara, Türkiye, soner@metu.edu.tr
} sunulmuştur. [This study was partly presented at the $12^{\text {th }}$ International Computer \& Instructional Technologies Symposium in Izmir, May 02- 


\section{Extended Abstract}

\section{Introduction}

2017 Student Selection and Placement Exam Handbook indicated that there are total of 63 Computer Education and Instructional Technology (CEIT) Departments at state and private universities in Turkey and Turkish Republic of Northern Cyprus accepting students. However, according to 2017 placement results, none of the students chose seven of those departments and nine or less number of students were placed in 38 of them. While four of the departments have fully filled their quotas, $22 \%$ of them have filled their capacity between $20 \%$ and $60 \%$. In the literature, a limited number of research about the occupational and departmental preferences of university students in general, and CEIT student in particular, were found. According to the findings of these studies, university entrance exam score, interest in the area, the suitability of the area to personality characteristics, the possibility of finding a job, family effect, the location of the city, possible changes in the examination system are the most common factors affecting students' preferences (Korkut-Owen, Kepir, Özdemir, Ulaş \& Yılmaz, 2011; Özyürek \& Kılıç-Atıc1, 1993; Sarıkaya \& Khorshid, 2009). In this respect, there is a need to conduct research to determine reasons that affect students' preferences of CEIT departments. In the present study, it is aimed to explore the university and department-related features that affect the preferences of students from CEIT departments that either fully or between $20 \%-60 \%$ filled their capacity.

\section{Method}

The data were gathered by survey research method from 290 students from 12 different CEIT departments which filled $20 \%$ or more of their quota. $33.8 \%$ of the students were enrolled in English preparatory class and $66.2 \%$ of them were freshman. Of the participants, with an average age of 19.5, $49 \%$ were female and $51 \%$ were male.

As data collection tools, two different Likert type scales were developed. Expert opinion was taken on the content validity of the scales. A pilot study was conducted with 58 students and their opinions were obtained on the language and intelligibility of the items. Then, the scales were administered to 290 students and the construct validity and reliability of the scales were tested by exploratory factor analysis. The first scale, the impact of university-related features on preferences, composed of 14 items and four dimensions (advice, location, opportunity, and reputation). These four dimensions explained $57.5 \%$ of the total variance and the load values of the items ranged from .818 to .551. According to the reliability analysis of the scale, internal consistency coefficient was calculated as .75. The second scale, the impact of department-related features on preferences, composed of nine items and two dimensions (quality, advice). For this scale, the load values of the items ranged between .827 and .568; and the dimensions explained $55.3 \%$ of the total variance. Internal consistency coefficient was calculated as .80 .

In the analysis of the data, descriptive and comparative statistical analyses were used. In descriptive statistics, frequency, percentage and mean values were calculated. In comparative analysis, t-test was applied.

\section{Findings}

Findings of the study revealed that $73 \%$ of the students preferred to study at a different major rather than CEIT. $70.4 \%$ of those students actually preferred to study at different majors in STEM fields (Basic Science, Engineering, Architecture, and Health etc.), $14.1 \%$ preferred to study at majors such as Law, City and Regional Planning, Psychology, and etc., $12 \%$ preferred to major in an educational field. According to the findings related to university-specific characteristics that affect students' preferences, the students were influenced respectively by university reputation $(\bar{X}=5.01)$, location $(\bar{X}=4.17)$, opportunities $(\bar{X}=3.37)$, and advice $(\bar{X}=1.97)$ dimensions. Statistically significant differences were found between the students in the CEIT departments that fully filled and did not fill their quota in terms of university opportunities and university location dimensions. Accordingly, the students who were enrolled in the CEIT departments that fully filled their quota $(\bar{X}=3.54)$, took the university opportunities into consideration more than the other students $(\bar{X}=3.16),[t(288)=2.756, p<$ .01]. On the other hand, the university location affected students preferences who were enrolled in CEIT departments that did not fill their quota $(\bar{X}=4.69)$ compared to others $(\bar{X}=0.73),[t(288)=-6.687, p<.01]$.

The findings related to the characteristics of the department that affect students' preferences showed that the quality dimension $(\bar{X}=3.72)$ was more effective than the advice dimension $(\bar{X}=1.73)$. Statistically significant differences were found between the students in the CEIT departments that fully filled and did not fill their quota in terms of department quality dimension. Accordingly, the department quality affect students' preferences who were enrolled in CEITS that fully filled their quota $(\bar{X}=3.87)$ compared to others $(\bar{X}=3.55),[t(288)=2.048, p$ 
$<.05]$. While mean of the students' opinions about university-related features affecting their preference was 3.63 out of 6, mean of students' opinions about department-related features affecting their preference was 2.72 .

\section{Discussion and Conclusion}

According to the studies conducted in Turkey; teachers, OSYM resources, occupational guide books (Özyürek \& Kılıç-Atıc1, 1993), parents (Özyürek \& Kılıç-Atıcı, 1993; Sarıkaya \& Khorshid, 2009), and relatives working in the related profession (Sarıkaya \& Khorshid, 2009) were the channels that students used while preparing their preference lists. On the other hand, the web pages of universities and departments can be a factor affecting their decision-making. Indeed, most of the students who participated in our research stated that they visited the website of the CEIT department where they wished to study in their decision process.

Among the characteristics of the university, the reputation of the university has emerged as the most dominant factor affecting students' preferences. Among the characteristics of the university, the location of the university; and among the characteristics of the department, the quality of the department stand out as two other factors affecting students' preferences. University opportunities and department quality dimensions have affected the preferences of the students in CEIT departments which fully filled their quota more than the students in CEIT departments which did not fill their quota. University location dimension has affected the preferences of the students in CEIT departments which did not fill their quota more than others. These results showed that the quality of the department does not have a separate effect from the quality of the university. Therefore, universities should be considered as a whole and the importance of providing the necessary financial and moral support to increase the quality of the existing universities should be emphasized in every platform. In addition, the quality of the department has been found to be an important factor affecting the preferences of CEIT students. Contrary to the students who stated that university opportunities as a reason for preference, it is worth noting that this result is in favor of CEIT students who fill their quota.

It is expected that the results of the research will be beneficial for the CEIT departments in terms of getting to know their target audience, developing new strategies to increase the quality of the department, and taking into account the fact that the quality of the department is perceived together with the quality of the university. 


\section{Giriş}

ÖSYS Yükseköğretim Programları ve Kontenjanları Kılavuzuna göre, 2017 yılında Türkiye ve KKTC'deki devlet ve vakıf üniversiteleri bünyesindeki 63 Bilgisayar ve Öğretim Teknolojileri Eğitimi bölümü, öğrenci kabul etmiştir (ÖSYM, 2017) . Bu bölümlerden 53'ü devlet, beşi vakıf, beşi ise KKTC üniversiteleridir. Ne var ki, 2017 yerleştirme sonuçlarına göre bu bölümlerden sadece dördü (\% 6) kontenjanını tam doldururken, 14'ü (\% 22) ise kapasitesinin \% 20 - \% 60'ını doldurmuștur (YÖK, 2017). Bölümlerden yedisine (\% 11) hiç öğrenci yerleşmemiş, 38'ine (\% 60) ise kapasitenin \% 20'si ve altında öğrenci yerleşmiştir. Toplamda bakıldığında, 2017-2018 eğitim-öğretim yılındaki 2661 kişilik BÖTE öğrenci kapasitesinin 525'inin ilk yerleştirme ile dolduğu, ek yerleştirme sonucunda yerleşen 31 öğrenci de eklendiğinde toplam kapasitenin sadece \% 21'inin kullanılabildiği görülmektedir.

2017 yılı Lisans Yerleştirme Sınavı verilerine göre BÖTE bölümleri tercih listelerinde toplam 4257 kez yer almıştır (YÖK, 2017). Tercihlerinde BÖTE'ye yer veren bu öğrencilerden \% 12'si, ilk yerleştirmede bölüme kayıt hakkı kazanmışır.

Germeijs ve Verschueren (2006) lise öğrencilerinin meslek seçimi sürecini 6 aşamada açıklamaktadır: (1) meslek seçimi yapma ve bunun gerekliliğine ikna olma, (2) kendini keşfetme, (3) meslek alternatiflerini keşfetme, (4) daraltılmış alternatiflerle ilgili daha detaylı bilgi sahibi olma, (5) karar aşaması ve (6) kesin karara varma. Ülkemizdeki üniversite seçme ve yerleştirme sürecinin bir gereği olarak öğrencilerin, beş ve altıncı adımları, açıklanan yerleştirme puanlarına ve daha önceki yıllarda bu puanlarla hangi bölümlere yerleşilebildiğine dair verilere göre şekillendirebilme imkânları bulunmaktadır. Ancak 2017 yılında BÖTE bölümleri için puan türü değişikliğine gidilmiş ve BÖTE bölümünü düşünen öğrencilerin elinden bu imkân alınmıştır. Öğrencilerin tercih listelerinde farklı mühendislik alanlarından diş hekimliğine, öğretmenlik branşlarından hemşirelik ve ebeliğe kadar çok geniş bir yelpazede bölümlere yer vermeleri (YÖK, 2017) ilk dört aşamada değerlendirmeye aldıkları farklı meslek alternatiflerini son iki aşamada azaltamadıklarını akla getirmektedir.

Alanyazında yapılan taramalarda, genel olarak üniversite, özel olarak da BÖTE bölümü öğrencilerinin meslek ve bölüm tercihleri ile ilgili sınırlı sayıda araştırmaya rastlanmıştır. Bu araştırmaların bulgularına göre, öğrencilerin tercihlerini etkileyen faktörler arasında en sık karşılaşılanı üniversite giriş sınavı puanıdır (Gezgin, 2015; Korkut-Owen, Kepir, Özdemir, Ulaş ve Yılmaz, 2011; Özsoy, Özsoy, Özkara ve Memiş, 2010; Özyürek ve Kılıç-Atıcı, 1993; Sarıkaya ve Khorshid, 2009). Öğrencilerin bölüm tercihlerini etkileyen diğer faktörler arasında ilgi (Korkut-Owen ve diğ., 2011; Özyürek ve Kılıç-Atıcı, 1993), alanın kişilik özelliklerine uygunluğu, iş bulma olanağının yüksekliği (Korkut-Owen ve diğ., 2011), aile etkisi, bulunduğu şehir, sınav sistemindeki olası değişiklikler (Sarıkaya ve Khorshid, 2009) bulunmaktadır. Diğer yandan Gezgin (2015), BÖTE öğrencileri ile yaptığı çalışmada üniversitenin bulunduğu şehrin ve buradaki yaşam şartlarının etkisi olmadığını bulgulamıştır.

Lise öğrencilerinin üniversite ve bölüm seçme sürecinde tercihlerini etkileyen en güçlü unsurların (i) kurumun algılanan değeri, (ii) görüşlerine önem verilen kişilerin tavsiyeleri ve (iii) öğrenci tarafından yapılan araştırma ve toplanan bilgiler olduğu belirtilmektedir (The National Research Center for College \& University Admissions NRCCUA, 2014). Kurumun algılanan değeri, öğrenciyi iş gücüne katılmaya ne kadar hazırladığı, akademik, sosyal ve fiziksel çevre ile ilgili algılar ile burs ve diğer finansal imkânlardan etkilenmektedir (NRCCUA, 2014). Bu anlamda ülkemizde Yüksek Öğretim Kurumu'nca 2016'dan bu yana aktif olan YÖK Atlas uygulamasında Yüksekögretim Süreç ve Çıktı Göstergeleri ve Mezun Başarı Atlası başlıkları altında yapılan bilgilendirmelerin karar verme açısından önemli olacağı düşünülebilir. Diğer unsur olan görüşlerine önem verilen kişiler arasında da ebeveynler, rehber öğretmenler, arkadaşlar, ilgili üniversitede okuyan/okumuş tanıdıklar sayılmaktadır.

2017 yılında BÖTE bölüm kontenjanları ile ilgili yaşanan durumun arkasında alanyazında bahsedilen bu etkenlerden hangilerinin ne ölçüde var olduğunu anlayabilmek üzere, yerleşen öğrencilerin BÖTE bölümlerini tercihlerini etkileyen sebeplerin belirlenmesi gerektiği düşünülmüștür. Araştırmada kontenjanını tam dolduran ile $\% 20$ - \% 60 bandında dolduran BÖTE’lerdeki öğrencilerin tercihlerinde üniversite ve bölümlerle ilgili özelliklerin etkisinin incelenmesi amaçlanmıştır. Bu çerçevede araştırma soruları aşağıdaki gibi belirlenmiştir:

1. Katılımcıların özelliklerine ve tercihlerine yönelik genel bilgiler nelerdir?

2. Üniversite ile ilgili özelliklerin tercihlere etkisine yönelik öğrenci görüşleri nelerdir?

3. Öğrencilerin, üniversitelerin özelliklerinin tercihlerini etkilemesi ile ilgili görüşleri BÖTE’lerin kontenjan doldurma durumuna göre farklılık göstermekte midir?

a) Öğrencilerin, üniversitelerin sundukları olanakların tercihlerini etkilemesi ile ilgili görüşleri, BÖTE'lerin kontenjan doldurma durumuna göre farkl1lık göstermekte midir?

b) Öğrencilerin, üniversitelerin şehir içinde bulunduğu konumlarının tercihlerini etkilemesi ile ilgili görüşleri, BÖTE’lerin kontenjan doldurma durumuna göre farklılık göstermekte midir? 
c) Öğrencilerin, başkalarının tavsiye ediyor olmasının tercihlerini etkilemesi ile ilgili görüşleri, BÖTE'lerin kontenjan doldurma durumuna göre farklılık göstermekte midir?

d) Öğrencilerin, üniversitenin namının tercihlerini etkilemesi ile ilgili görüşleri, BÖTE’lerin kontenjan doldurma durumuna göre farkl1lık göstermekte midir?

4. Öğrencilerin seçtikleri bölüme yönelik tercihlerini etkileyen özelliklerle ilgili görüşleri nedir?

5. Öğrencilerin, seçtikleri bölümün özelliklerinin tercihlerini etkilemesi ile ilgili görüşleri, BÖTE’lerin kontenjanlarını doldurma durumuna göre farklılık göstermekte midir?

\section{Yöntem}

\section{Araştırmanın Modeli}

2017-2018 akademik y1lında BÖTE bölümlerine yerleşen öğrencilerin tercihlerini etkiyen faktörleri belirlemek amacıyla yapılan bu çalışmada, araştırma modeli olarak tarama modeli kullanılmıştır.

\section{Çalışma Grubu}

Araştırmada, kontenjanını \% 20 ve üstü oranda doldurmuş 12 farklı BÖTE bölümündeki 290 öğrenciden veri toplanmıştır. Öğrencilerin üniversitelere göre dağılımları, üniversitelerin kontenjanları, yerleşen öğrenci sayıları, yerleşenler arasından ulaşılan öğrenciler ve çalışma grubu içindeki oranları -yerleşen öğrenci sayısına göre sıralı olarak- Tablo 1'de gösterilmiştir.

Tablo 1

Ögrencilerin Üniversitelere Göre Dağılımı

\begin{tabular}{|c|c|c|c|c|c|}
\hline Üniversite & $\begin{array}{c}\text { Kontenjan } \\
n\end{array}$ & $\begin{array}{c}\text { Yerleşen } \\
\text { Öğrenci Sayısı } \\
n\end{array}$ & $\begin{array}{c}\text { Yerleşme } \\
\text { Oranı } \\
\%\end{array}$ & $\begin{array}{c}\text { Çalışma Grubu } \\
n\end{array}$ & $\begin{array}{c}\text { Çalışma Grubu } \\
\%\end{array}$ \\
\hline Yıldız Teknik Üniversitesi & 60 & 62 & 100 & 52 & 17.9 \\
\hline Boğaziçi Üniversitesi & 60 & 60 & 100 & 30 & 10.3 \\
\hline Hacettepe Üniversitesi & 60 & 59 & 100 & 56 & 19.3 \\
\hline ODTU & 40 & 40 & 100 & 19 & 6.6 \\
\hline Marmara Üniversitesi & 60 & 35 & 58 & 30 & 10.3 \\
\hline İstanbul Üniversitesi & 45 & 24 & 53 & 22 & 7.6 \\
\hline Ege Üniversitesi & 60 & 24 & 40 & 17 & 5.9 \\
\hline Ankara Üniversitesi & 60 & 18 & 30 & 12 & 4.1 \\
\hline Balıkesir Üniversitesi & 40 & 12 & 30 & 11 & 3.8 \\
\hline Çukurova Üniversitesi & 45 & 13 & 29 & 14 & 4.8 \\
\hline Uludağ Üniversitesi & 60 & 16 & 27 & 15 & 5.2 \\
\hline Anadolu Üniversitesi & 60 & 13 & 22 & 12 & 4.1 \\
\hline Toplam & & & & 290 & 100 \\
\hline
\end{tabular}

Tablo 1'deki üniversitelerden Orta Doğu Teknik Üniversitesi, Hacettepe Üniversitesi, Boğaziçi Üniversitesi ve Yıldız Teknik Üniversitesi’nde bulunan BÖTE Bölümleri kontenjanlarını tam doldururken; Ankara Üniversitesi, Balıkesir Üniversitesi, Uludağ Üniversitesi, Ege Üniversitesi, Anadolu Üniversitesi, İstanbul Üniversitesi, Marmara Üniversitesi ve Çukurova Üniversitesi kontenjanlarını \% 20 - \% 60 bandında doldurmuştur. Araştırmaya dâhil edilenlerden Yıldız Teknik, Boğaziçi ve Ortadoğu Teknik üniversiteleri zorunlu hazırlık veren üniversiteler olup, öğrencilerin 98 ' $\mathrm{i}$ (\% 33.8) İngilizce hazırlık, 190 '1 ise (\% 66.2) 1. sınıfta öğrenim görmektedir. Çalışma grubunu oluşturan öğrencilerin 142'si (\% 49) kadın, 148'i (\% 51) erkektir. Öğrencilerin yaşları 17 ile 32 arasında değişmekle beraber yaş ortalaması $19.5^{`}$ tir.

\section{Veri Toplama Araçları ve Verilerin Analizi}

Veri toplama aracı olarak araştırmacılar tarafından, öğrencilerin demografik özelliklerini belirlemeye yönelik bir bilgi formu ile üniversite tercihlerini etkileyen faktörleri belirlemeye yönelik iki ölçek geliştirilmiş̧ir. Bilgi formu, öğrencilerin cinsiyeti, sınıfı, mezun olduğu lise türü, BÖTE'den önceki tercihleri gibi değişkenleri incelemek amacıyla hazırlanmıştır. Ölçekler ise üniversite ile ilgili özelliklerin ve bölüm ile ilgili özelliklerin öğrencilerin tercihlerine etkisini saptamak amaciyla altılı Likert tipinde geliştirilmiştir. Ölçeklerin kapsam geçerliği için uzman görüşüne başvurulmuş, 58 ögrenciyle pilot çalışması yapılarak maddelerin dili ve anlaşılırlığ ile ilgili görüş alınmıştır. 
Ölçeklerin yapı geçerliği açımlayıcı faktör analizi yapılarak 290 öğrenci ile test edilmiştir. Çalışma grubu için Kaiser-Mayer-Olkin (KMO) değeri .83'dür. Bartlett küresellik testi sonuç değeri de istatistiksel olarak anlamlı bulunmuştur $\left[X^{2}=694.562, \mathrm{sd}=91, \mathrm{p}<.000\right)$. Bu değerler veri setinin faktör analizi için uygun olduğunu göstermektedir (Büyüköztürk, 2006). Üniversite ile ilgili özelliklerin tercihlere etkisi ölçeği 14 madde ve dört alt boyuttan (tavsiye, konum, olanaklar, nam) oluşmuştur. Faktör analizinde maddeler farklı özelliklere yönelik olduğu için Varimax döndürme metodu kullanılmış olup bu dört boyut, toplam varyansın \% 57.5'ini açıklamaktadır. Faktör analizi sonunda, yük değerleri .818 ile .551 arasında değiștiği ve birden fazla boyutta yüksek yük değeri veren maddeye rastlanmadığı için madde çıkarılmamıştır. Ölçeğin Tavsiye alt boyutunda üniversite tercihinde ailenin, rehber öğretmeninin ya da diğer kişilerin tavsiyesinin etkili olup olmadığı, etkili olduysa ne kadar etkili olduğunu saptamak amaçlanmıştır. Konum alt boyutunda, üniversitenin bulunduğu şehir, şehirde bulunduğu konum ve ulaşım kolaylığı maddeleri bulunmaktadır. Olanaklar alt boyutu, üniversitenin kampüs içinde eğitim veriyor olması, yurt olanakları, sunduğu kültür/sanat/spor/kulüp olanakları ve teknokentin olması maddelerini içermektedir. Son alt boyut olan Nam ise, devlet üniversitesi olması ve üniversitenin toplum içindeki itibarlı konumu (namı) maddelerini içermektedir. Katılımcıların ölçek maddelerine verdikleri cevaplar Hiç etkili olmadı dan Çok fazla etkili oldu ya doğru 1'den 6'ya kadar puanlanmıştır. Veri toplama aracının güvenirliğini hesaplamak için Cronbach Alfa $(\alpha)$ iç tutarlılık katsayısı hesaplanmıştır. Güvenirlik katsayıları Nam boyutu için .46, Tavsiye boyutu için .70, Konum boyutu için .74 ve Olanaklar boyutu için .66 bulunmuştur. Ölçeğin tamamı için güvenirlik katsayısı .75 olarak hesaplanmıştır. Düşük madde sayılı ölçeklerde yüksek güvenirlik katsayısını elde etmek zor olabilmektedir; ancak genel ölçek güvenirlik katsayısının .70'in üzerinde olması beklenmektedir ve bu çalışmada bu beklentinin karşılandığı görülmektedir (Pallant, 2013, s. 109).

Bölüm ile ilgili özelliklerin tercihlere etkisi ölçeği yine altılı Likert tipinde olup 9 madde ve iki boyuttan (nitelik, tavsiye) oluşmaktadır. Başta beş boyutlu bir yapı veren ve 13 maddeden oluşan ölçekten aşamalı olarak maddeler çıkarılmış ve sonuçta iki boyutlu ve 9 maddeli bir ölçek elde edilmiştir. Elde edilen ölçekteki Nitelik ve Tavsiye boyutları toplam varyansın \% 55.3'ünü açıklamakta ve madde yük değerleri .827 ile .568 arasında değişmektedir. Nitelik alt boyutunda bölümün kalitesi, akademik kadrosunun güçlü olması, mezunlarının iyi yerlerde iş bulması, bölüm programında seçmeli ders alternatiflerinin yer alması ve bölümün aktif kulüp etkinliklerinin bulunması maddeleri bulunmaktadır. Tavsiye alt boyutunda ise rehber öğretmenin, diğer kişilerin (arkadaş, öğretmen, akraba), ailemin okumam için ısrar etmesi ve üniversite tanıtım günlerinde bölümü tercih etmeye ikna olmam maddeleri bulunmaktadır. Veri toplama aracının iç tutarllık güvenirlik analizi sonuçlarına göre, Nitelik alt boyutunun güvenirlik katsayısı .83 iken, Tavsiye alt boyutunun güvenirlik katsayıs1 .75 bulunmuştur. Ölçeğin tamamı için güvenirlik katsayısı .80 olarak hesaplanmışıır.

Verilerin analizinde betimsel ve karşılaştırmalı istatistiksel analizlere başvurulmuştur. Verilerin normal dağılım gösterip göstermediğini belirlemek amacıyla basıklık-çarpıklık değerlerine bakılmış ve bu değerlerin \pm 2 aralığında olduğu saptanmıştır. Veriler normal dağılım gösterdiği için parametrik testler kullanılmıştır. Betimsel istatistiklerde frekans, yüzde ve ortalama değerler hesaplanmıştır. Karşılaştırmalı analizlerde ise bağımsız örneklemler için t-testi uygulanmıştır.

\section{Bulgular}

\section{Katılımcıların Özellikleri ve Tercihleriyle ilgili Genel Bilgiler}

Araştırmanın birinci sorusu, katılımcıların mezun oldukları lise türü, üniversite eğitimi sırasında kaldıkları yerler, BÖTE yerine okumak istedikleri bölüm gibi genel özelliklerini belirlemeye yöneliktir. Araştırmaya, 2017 üniversite yerleştirme sonuçlarına göre kontenjanını \% 20 ve üstü doldurmuş 12 farklı BÖTE bölümüne kayıtlı 290 öğrenci katılmıştır. Çalışma grubundaki öğrencilerin bazı demografik bilgilere göre dağılımları Tablo 2'de gösterilmiş̧tir.

Tablo 2 incelendiğinde, öğrencilerin yarısından fazlasının Anadolu Lisesi mezunu olduğu görülmektedir. Çalışma grubundaki öğrencilerin büyük çoğunluğu (\% 90.7) bulundukları BÖTE bölümüne, üniversite sınavına birinci veya ikinci girişlerinde yerleşmişlerdir. Yine Tablo 2'ye göre öğrencilerin yarısından fazlası (\% 56.6) ailesi ile birlikte, \% 27'si ise öğrenci evinde yaşamaktadırlar. Aynı çalışmanın bir başka bulgusu da, öğrencilerin $\%$ 54.5'inin tercih ettikleri üniversite ile mezun oldukları lisenin aynı ilde olduğu yönündedir. Öğrencilerin \% 45.5'inin ise farklı ildeki bir üniversiteyi tercih ettiği saptanmıştır. 
Tablo 2

Ögrrencilerin Mezun Oldukları Lise Türü, Üniversite Sinavına Kaçıncı Girişlerinde BÖTE Bölümüne Yerleştikleri ve Üniversite Eğitimleri Sırasında Kaldıklarl Yerlere Dair Dağılımları ve Oranları

\begin{tabular}{lrr}
\hline Değişkenler & $n$ & $\%$ \\
\hline Mezun oldukları lise türü̈ & & 54.1 \\
Anadolu Lisesi & 157 & 19 \\
Meslek, Teknik, Endüstri, Ticaret Lisesi & 55 & 8.6 \\
Temel Lise & 25 & 4.8 \\
Anadolu Öğretmen Lisesi & 14 & 4.5 \\
İmam Hatip Lisesi & 13 & 0.3 \\
Fen Lisesi & 1 & 8.6 \\
Diğer & 25 & 53.8 \\
Universite sınavina kaçıncı girişte BÖTE bölümüne yerleştikleri & 36.9 \\
1. giriş & & 4.5 \\
2. giriş & 156 & 1.7 \\
3. giriş & 107 & 0.3 \\
4. giriş & 13 & 2.8 \\
5. giriş & 5 & 56.6 \\
Bilinmiyor & 1 & 27.6 \\
Universite eğitimi strasında kaldılarl yerler & 8 & 7.9 \\
Aile ile birlikte & & 2.1 \\
Öğrenci yurdunda & 164 & 5.9 \\
Öğrenci evinde & 80 & \\
Bir akrabada & 23 & 6 \\
Diğer & 17 & \\
\hline
\end{tabular}

YÖK Atlas (2017) verilerinin incelenmesinden de BÖTE bölümlerinin tercih listelerindeki sıra ortalamasının BÖTE'yi tercih eden tüm öğrenciler için 6.2 - 17.7 arasında olduğu ve genel ortalamanın 12 olduğu anlaşılmaktadır. 2017 yılında tercih yapan tüm adaylar incelendiğinde; X (belirli bir) üniversitesindeki BÖTE bölümünü tercih listesine yazan ögrrenci sayısının bölüm başına 256 - 9 arasında değiştiği ve ortalamasının 79 olduğu görülmektedir (YÖK, 2017). Kontenjanını tam dolduran dört bölüm için bu değer ortalaması 240'a yükselirken, \% 20 - \% 60 arası dolduranlar için $125^{\prime}$ e, sıfır ilâ dokuz arasında öğrenci yerleşen bölümlerden oluşan üçüncü grup için ise 42'ye düşmektedir. X üniversitesi, BÖTE bölümündeki tek bir kontenjana talip olan aday saylsı 11.5 - 0.2 arasında değişmekte; kontenjanını dolduran grup için ortalama 4.3 olan aday sayısı, kontenjanını \% 60 dolduran grup için 2.5 'e, kontenjanını \% 20 ve altı dolduran için ise 1.5 'e gerilemektedir.

Katılımcılara, yerleştikleri BÖTE bölümünden bir önceki tercihlerinin ne olduğu sorulmuş ve sonuçlar Tablo 3 ’te gösterilmiştir.

Tablo 3

Öğrencilerin Yerleştikleri Bölümden Bir Önceki Tercihlerine Dair Dă̆ıllımları ve Oranları

\begin{tabular}{lrr}
\hline Bölümler & $n$ & $\%$ \\
\hline Sayısal bölümler (Temel bilimler, Mühendislik, Mimarlık, Sağlık, vb.) & 164 & 56.6 \\
Sözel ve eşit ağırlıklı bölümler (Hukuk, Şehir Bölge Planlama, Psikoloji, vb.) & 13 & 4.5 \\
Öğretmenlik bölümleri (BÖTE dahil) & 50 & 17.2 \\
Toplam & 227 & 90 \\
\hline
\end{tabular}

Tablo 3 incelendiğinde, öğrencilerin yarısından fazlasının (\% 56.6), yerleştikleri BÖTE bölümünden bir önceki sırada, Fizik, Kimya, Matematik, vb. temel bilimler, çeşitli mühendislikler, mimarlık ve sağlık ile ilgili bölümleri tercih ettikleri görülmektedir.

Öğrencilere, yerleşmiş oldukları üniversitenin BÖTE bölümü dışında okumak istedikleri başka bölüm olup olmadığı sorulmuş ve \% 73'ü Evet yanıtı vermiştir. Evet yanıtı veren öğrencilerin hangi bölümlerde okumak istedikleri sorusuna verdikleri yanıtlar Tablo 4'de gösterilmiştir. 
Tablo 4

Öğrencilerin BÖTE Yerine Okumak İstedikleri Bölümlere Dair Dağılımlar ve Oranları

\begin{tabular}{lrr}
\hline Bölümler & $n$ & $\%$ \\
\hline Sayısal bölümler (Temel bilimler, mühendislik, mimarlık, sağlık vb.) & 150 & 70.4 \\
Sözel ve eşit ağırlılı bölümler (hukuk, şehir bölge planlama, psikoloji vb.) & 30 & 14.1 \\
Öğretmenlik bölümleri (BÖTE hariç) & 25 & 11.7 \\
Toplam & 205 & 70.1 \\
\hline
\end{tabular}

Tablo 4, öğrencilerin üçte ikisinden fazlasının (\% 70.4) BÖTE yerine temel bilimler, mühendislik, sağlık vb. bölümlerde okumak istediklerini göstermektedir. Nitekim YÖK Atlasta (YÖK, 2017) yer alan bulgulara göre, Lisans Yerleştirme Sınavı sonucunda BÖTE'lere yerleşen ögrencilerin tercih listelerinde yer verdikleri BÖTE programı adeti bölümlere göre 1 - 357 arasında değişmektedir ve tüm BÖTE'ler için ortalaması 38'dir (YÖK, 2017). Diğer taraftan BÖTE'lere yerleşen öğrencilerin tercih listelerinde yer verdikleri farkl program adeti ortalaması ise tüm BÖTE'ler için 119'dur ve bölümler bazında 0 - 783 arasında değişmektedir. İlk gruptaki dört bölüm için bu iki değerin ortalamaları 188 ve 610 iken, ikinci gruptaki BÖTE'ler için bu ortalamaların sırasıyla 74 ve 228 olduğu görülmektedir. Üçüncü gruptaki BÖTE'ler için ise aynı ortalamalar yine sirasıyla 8 ve 25 'tir. $\mathrm{Bu}$ verilere dayalı olarak, BÖTE'lere yerleşen öğrencilerin tercihte bulunurken yazdıkları BÖTE programı adetinin yaklaşık üç katı sayıda farklı programa tercih listelerinde yer verdikleri söylenebilir.

Katılımcı öğrencilere, yerleştikleri üniversitenin BÖTE bölümünden hangi kanallar aracılı̆̆ıla haberdar oldukları sorulmuş, birden fazla cevap işaretleyebilecekleri belirtilmiş ve sonuçlar Tablo 5 'te gösterilmiştir.

Tablo 5

Öğrencilerin Yerleştikleri Bölümden Nasıl Haberdar Olduklarına Dair Dă̆ılımları ve Oranları

\begin{tabular}{lrr}
\hline Haber kaynağı & $f$ & $\%$ \\
\hline YÖK Atlas & 81 & 27.9 \\
ÖSYS Tercih Kılavuzu & 81 & 27.9 \\
Aile & 60 & 20.7 \\
Bölüm Web sitesi & 55 & 19 \\
Arkadaş & 50 & 17.2 \\
Okul Bilişim Teknolojileri öğretmeni & 48 & 16.6 \\
Okul rehber öğretmeni & 47 & 16.2 \\
BÖTE mezunu birisi & 37 & 12.8 \\
Üniversite tanıtım günü & 27 & 9.3 \\
Dershane rehber öğretmeni & 19 & 6.6 \\
Basın & 9 & 3.1 \\
Diğer & 28 & 9.7 \\
\hline
\end{tabular}

Tablo 5 incelendiğinde, öğrencilerin yerleștikleri BÖTE bölümünden en çok YÖK Atlas, ÖSYS tercih kılavuzu ve aileleri aracılığ 1 ile haberdar oldukları söylenebilir. Diğer yandan öğrencilerin bölümden web sitesi ile haberdar olma ortalaması \% 19 ile 4. sırada yer almıştır. Bunlara ek olarak, araştırma kapsamındaki 290 öğrencinin, bilgi formu verilerine dayanarak; öğrencilerin \% 67.6'sının tercihlerini yaparken, yerleştikleri BÖTE bölümünün web sitesini, \% 42.4'ünün diğer üniversitelerin BÖTE bölümlerinin web sitelerini, \% 67.2'sinin yerleştikleri BÖTE bölümünün ders programını inceledikleri ve \% 21.7'sinin üniversite bölüm tanıtım gününe geldikleri tespit edilmiştir.

\section{Öğrencilerin Tercihlerini Etkileyen Üniversiteye Yönelik Özellikler ile ilgili Görüşleri}

İkinci araştırma sorusu, öğrencilerin tercihlerini etkileyen üniversiteye yönelik özelliklerle ilgili görüşlerini belirlemeye yöneliktir. Buna göre altılı Likert tipindeki ölçekle toplanan öğrenci görüşleri Tablo 6'da gösterilmiştir. Tablo 6 incelendiğinde; üniversitenin namı boyutunun, öğrenci tercihinde en yüksek değere sahip $(\bar{X}=5.01)$ boyut olduğu görülmektedir. Bunu, üniversitenin konumu $(\bar{X}=4.17)$, üniversitenin sunduğu olanaklar $(\bar{X}=3.37)$ boyutları izlemektedir. Tavsiye alt boyutu, en düşük tercih faktörü durumundadır $(\bar{X}=$ 1.97).

Tüm boyutlar içerisinde, devlet üniversitesi olması ve toplum içindeki itibarlı konumu gibi özelliklerle temsil edilen üniversitenin namı boyutu, 6 üzerinden 5.01 ortalama ile öğrencilerin tercihlerini etkileyen en önemli boyut olmuştur. $\mathrm{Bu}$ bulgu, üniversite yönetimlerinin yıllar içinde edinilen itibarın ne kadar önemli olduğunu görmeleri açısından çok değerli bir bulgudur. Dolayısıyla, bölümün niteliği ne kadar yüksek olursa olsun, 
üniversitenin namı öğrenci tercihlerini etkileyen en güçlü boyutlardan biri olduğu için üniversitenin bir bütün olarak ele alınması çok önemlidir. Yine üniversitenin bulunduğu konum boyutunun, üniversitenin sunduğu olanaklar boyutundan yüksek olması dikkat çekici bir başka bulgudur. Bulgu, BÖTE öğrencilerinin tercihlerini, üniversitenin bulunduğu şehir, şehir içindeki konumu, ulaşım kolaylığı vb. özelliklerinin; üniversitedeki kampüs yaşamı, kulüp etkinlikleri, sanatsal ya da teknolojik destekler vb. olanaklarından daha fazla etkilediğini göstermektedir. O halde üniversiteler, iç olanaklarını artırmanın yanında ve ötesinde, konumlandıkları şehrin olanaklarına erişim ve bunların artırılması konusunda da aktif olmalıdırlar.

Tablo 6

Üniversite ile İlgili Özelliklerin Tercihlere Etkisine Yönelik Öğrenci Görüşlerine İlişkin Dağılımlar

\begin{tabular}{|c|c|c|c|c|c|c|}
\hline Boyut & Madde & Min & Mak & Ort. & Ss & Ort. \\
\hline \multirow{5}{*}{ Tavsiye } & Bir yakınımın bu üniversitede okuyor olması & 1 & 6 & 2.29 & 1.77 & \multirow{5}{*}{1.97} \\
\hline & Ailemin bu üniversitede okumam için ısrar etmesi & 1 & 6 & 2.43 & 1.79 & \\
\hline & $\begin{array}{l}\text { Rehber öğretmenimin bu üniversitede okumam için ısrar } \\
\text { etmesi }\end{array}$ & 1 & 6 & 1.56 & 1.14 & \\
\hline & $\begin{array}{l}\text { Diğer kişilerin (arkadaş, ögrretmen, akraba) bu üniversitede } \\
\text { okumam için 1srar etmeleri }\end{array}$ & 1 & 6 & 1.99 & 1.57 & \\
\hline & $\begin{array}{l}\text { Üniversite tanıtım günlerinde bu üniversiteyi tercih etmeye } \\
\text { ikna olmam }\end{array}$ & 1 & 6 & 1.59 & 1.20 & \\
\hline \multirow{4}{*}{ Olanaklar } & Bu üniversitenin bir kampüs içinde eğitim veriyor olması & 1 & 6 & 4.43 & 1.43 & \multirow{4}{*}{3.37} \\
\hline & $\mathrm{Bu}$ üniversitede yurt olanağının bulunması & 1 & 6 & 2.15 & 1.70 & \\
\hline & Bu üniversitenin sunduğu kültür/sanat/spor/kulüp olanakları & 1 & 6 & 3.70 & 1.72 & \\
\hline & $\mathrm{Bu}$ üniversitede Teknokent'in bulunması & 1 & 6 & 3.20 & 1.79 & \\
\hline \multirow{3}{*}{ Konum } & Bu üniversitenin bulunduğu şehir & 1 & 6 & 5.17 & 1.18 & \multirow{3}{*}{4.17} \\
\hline & Bu üniversitenin şehir içinde bulunduğu konum & 1 & 6 & 3.83 & 1.74 & \\
\hline & Bu üniversitenin ulaşım kolaylığı & 1 & 6 & 3.51 & 1.81 & \\
\hline \multirow{2}{*}{ Nam } & Bu üniversitenin devlet üniversitesi olması & 1 & 6 & 4.98 & 1.25 & \multirow{2}{*}{5.01} \\
\hline & Bu üniversitenin toplum içerisindeki itibarlı konumu & 1 & 6 & 5.04 & 1.22 & \\
\hline
\end{tabular}

Tüm boyutlar içinde tavsiye boyutunun en düşük ortalamaya sahip olmasına karşın, bu boyutta yer alan aile ısrarı maddesinin en yüksek ortalamaya sahip madde $(\bar{X}=2.43)$ olması da dikkat çekici bulunmuştur.

\section{Öğrencilerin Tercihlerini Etkileyen Üniversiteye Yönelik Özellikler ile ilgili Görüşserinin Kontenjan} Doldurma Durumuna göre Farklııkları

Araştırmanın üçüncü sorusu, öğrencilerin, üniversitelerin özelliklerinin tercihlerini etkilemesi ile ilgili görüşlerinin bulundukları BÖTE bölümünün kontenjanını doldurma durumuna göre farklılık gösterip göstermediğini belirlemeye yöneliktir. Buna göre, yapılan İlişkisiz örneklemler için t-testi sonuçları Tablo 7'de gösterilmiştir.

Tablo 7

Üniversite Özelliklerinin Tercihlerini Etkileme Durumu Açısından BÖTE Bölümü Öğrencileri Arasındaki Farklıllı̆̆ İlişkin tTesti Sonuçları

\begin{tabular}{llllllll}
\hline Boyut & Kontenjan durumu & $\mathrm{N}$ & Ort. & Ss & sd & $t$ & $p$ \\
\hline \multirow{2}{*}{ Tavsiye } & Kont. dolduran & 157 & 1.87 & 0.93 & 288 & -1.772 & .077 \\
& Kont. doldurmayan & 133 & 2.09 & 1.13 & & & \\
Olanaklar & Kont. dolduran & 157 & 3.54 & 1.06 & 288 & 2.756 & $.006^{*}$ \\
& Kont. doldurmayan & 133 & 3.16 & 1.27 & & & \\
\multirow{2}{*}{ Konum } & Kont. dolduran & 157 & 3.73 & 1.21 & 288 & -6.687 & $.000^{*}$ \\
& Kont. doldurmayan & 133 & 4.69 & 1.22 & & & \\
\multirow{2}{*}{ Nam } & Kont. dolduran & 157 & 5.00 & 0.85 & 288 & -.166 & .869 \\
& Kont. doldurmayan & 133 & 5.02 & 1.15 & & & \\
\hline
\end{tabular}

$\bar{*} p<0.01$

Tablo 7'deki görüş ortalamalarına dayalı olarak, nam boyutunun tüm öğrenciler için en yüksek, tavsiye boyutunun ise en düşük öneme sahip tercih faktörü olduğu söylenebilir. Üniversitenin sunduğu olanaklar ve 
üniversitenin konumu boyutları açısından ise, kontenjanı dolduran ve doldurmayan BÖTE bölümü öğrencileri arasında istatistiksel olarak anlamlı farklılıklar bulunmuştur. Kontenjanını tam dolduran bölümlere yerleşen öğrenciler tercihlerini $(\bar{X}=3.54)$, yaparken üniversitenin sunduğu olanaklarl, kontenjanını doldurmayan üniversitedeki öğrencilere göre $(\bar{X}=3.16)$ daha fazla dikkate almaktadırlar $[t(288)=2.756, p<.01]$. Buna karşın, üniversitenin konumu ile ilgili özellikler, kontenjanını tam doldurmayan bölümlere yerleşen öğrencilerin tercihlerini $(\bar{X}=4.69)$, diğerlerine göre $(\bar{X}=0.73)$, daha çok etkilemektedir $[t(288)=-6.687, p<.01]$.

Söz konusu bulgular, kontenjanını tam dolduran BÖTE'leri tercih eden öğrencilerin tercihlerini üniversitenin kampüs içinde olması, yurt olanağının bulunması, kulüp etkinliklerin olması vb. özelliklerin daha fazla etkilediğini göstermektedir. Nitekim kontenjanı dolduran dört BÖTE Bölümü de bu olanaklara sahip üniversitelerde yer almaktadır. Diğer taraftan, kontenjanını tam doldurmayan BÖTE'leri tercih etmiş olan öğrenciler için ise üniversitenin bulunduğu şehir, üniversitenin şehir içinde bulunduğu konum ve üniversitenin ulaşım kolaylığı gibi özellikleri daha etkili olmuştur. Çalışma grubundaki öğrencilerin liseden mezun oldukları iller ile üniversiteye yerleştikleri iller incelendiğinde, \% 45.5' inin farklı, \% 54.5'inin ise aynı ilde bir üniversiteyi tercih ettikleri belirlenmiştir. Diğer yandan YÖK Atlas verileri, bu araştırmanın çalışma grubunda yer almayan ve yerleşen öğrenci sayısı 10'un altında olan üniversiteler için, kazanan öğrencilerin hemen hemen tamamının ya aynı ilden ya da komşu ilden geldiklerini göstermektedir (YÖK, 2017). Bu bulgu, üzerinde çalışılması gereken bir bulgudur.

\section{Öğrencilerin Seçtikleri Bölüme Yönelik Tercihlerini Etkileyen Özelliklerle ilgili Görüşleri}

Araştırmanın dördüncü sorusu, öğrencilerin tercihlerini etkileyen bölüme yönelik özelliklerle ilgili görüşlerini belirlemeye yöneliktir. Buna göre öğrencilerin görüşleri Tablo 8'de gösterilmiştir.

Tablo 8

Öğrencilerin Seçtikleri Bölüme Yönelik Tercihlerini Etkileyen Özelliklerle İlgili Görüşlerine İlişkin Dağllımlar

\begin{tabular}{|c|c|c|c|c|c|c|}
\hline Boyut & Madde & Min & Mak & Ort. & Ss & Ort. \\
\hline \multirow{4}{*}{ Tavsiye } & Ailemin bu BÖTE bölümünde okumam için 1srar etmesi & 1 & 6 & 2.13 & 1.68 & \multirow{4}{*}{1.73} \\
\hline & $\begin{array}{l}\text { Rehber öğretmenimin bu BÖTE bölümünde okumam için 1srar } \\
\text { etmesi }\end{array}$ & 1 & 6 & 1.48 & 1.08 & \\
\hline & $\begin{array}{l}\text { Diğer kişilerin (arkadaş, öğretmen, akraba) bu BÖTE bölümünde } \\
\text { okumam için 1srar etmeleri }\end{array}$ & 1 & 6 & 1.79 & 1.38 & \\
\hline & $\begin{array}{l}\text { Üniversite tanıtım günlerinde bu BÖTE bölümünü tercih etmeye } \\
\text { ikna olmam }\end{array}$ & 1 & 6 & 1.51 & 1.13 & \\
\hline \multirow{5}{*}{ Nitelik } & Bu BÖTE bölümünün akademik kadrosunun güçlü/yeterli olmas1 & 1 & 6 & 3.92 & 1.70 & \multirow{5}{*}{3.72} \\
\hline & $\begin{array}{l}\text { Aldığım duyumlara göre bu BÖTE bölümünün eğitim kalitesinin } \\
\text { yüksek olması }\end{array}$ & 1 & 6 & 4.17 & 1.69 & \\
\hline & Bu BÖTE bölümü mezunlarının iyi yerlerde iş bulması & 1 & 6 & 4.08 & 1.73 & \\
\hline & $\begin{array}{l}\text { Bu BÖTE bölümü programında seçmeli ders alternatiflerinin yer } \\
\text { alması }\end{array}$ & 1 & 6 & 3.21 & 1.82 & \\
\hline & Bu BÖTE bölümünde aktif kulüp etkinliklerinin bulunması & 1 & 6 & 3.23 & 1.83 & \\
\hline
\end{tabular}

Tablo 8'deki boyut ortalamaları incelendiğinde, nitelik boyutunun $(\bar{X}=3.72)$, tavsiye boyutundan $(\bar{X}=1.73)$ daha yüksek olduğu görülmektedir. Nitelik boyutunu temsil eden özellikler tek tek incelendiğinde ise en yüksek puanı, Aldığım duyumlara göre bu BÖTE bölümünün eğitim kalitesinin yüksek olması $(\bar{X}=4.17)$ maddesinin aldığı görülmektedir. Ölçeği cevaplayan grubun Tablo 6'da yer alan bulgulardaki üniversitenin olanaklarına yönelik özellikleri $(\bar{X}=3.37)$ ortalama ile değerlendirdikleri göz önünde bulundurulması gereken bir noktadır. Tablo 6 ve Tablo 8'de yer alan bulgular beraber değerlendirildiğinde, yine şu sonuç karşımıza çıkmaktadır: BÖTE öğrencileri tercihlerini yaparken üniversitenin konumu $(\bar{X}=4.17)$ ve namına $(\bar{X}=5.01)$ ”, bölümün niteliğinden $(\bar{X}=3.72)$ daha fazla değer vermişlerdir.

Öğrencilerin Tercihlerini Etkileyen Bölüme Yönelik Özellikler ile ilgili Görüşlerinin Kontenjan Doldurma Durumuna göre Farklılıkları

Araştırmanın beşinci sorusu, öğrencilerin, bölüm özelliklerinin tercihlerini etkilemesi ile ilgili görüşlerinin, bulundukları BÖTE bölümünün kontenjanını doldurma durumuna göre farklılık gösterip göstermediğini belirlemeye yöneliktir. Buna göre, yapılan ilişkisiz örneklemler için t-testi sonuçları Tablo 9'da gösterilmiştir. 
Tablo 9

Bölüm Özelliklerinin Tercihlerini Etkileme Durumu Açısından Kontenjanını Dolduran ve Doldurmayan BÖTE Bölümü Öğrencileri Arasındaki Farklılı̆̆a İlişkin t- Testi Sonuçları

\begin{tabular}{llcccccc}
\hline Boyut & Kontenjan durumu & $N$ & Ort & $S s$ & $s d$ & $t$ & $p$ \\
\hline \multirow{2}{*}{ Tavsiye } & Kont. dolduran & 157 & 1.65 & 0.90 & \multirow{2}{*}{288} & -1.321 & .187 \\
& Kont. doldurmayan & 133 & 1.81 & 1.10 & & & \\
\multirow{2}{*}{ Nitelik } & Kont. dolduran & 157 & 3.87 & 1.21 & \multirow{2}{*}{288} & 2.048 & $.042 *$ \\
\hline$* p<0.01$ & Kont. doldurmayan & 133 & 3.55 & 1.48 & & &
\end{tabular}

Tablo 9'a göre bölümün niteliği boyutu, kontenjanı doldurma durumlarına göre istatistiksel olarak anlamlı farklılık göstermektedir. Bölümün niteliği, kontenjanını tam dolduran bölümlere yerleşen öğrencilerin tercihlerini $(\bar{X}=3.87)$, kontenjanını tam doldurmayan bölümlere yerleşen öğrencilere göre $(\bar{X}=3.55)$, daha çok etkilemiştir $[t(288)=2.048, p<.05]$. Bölümün tavsiye edilmesi $[t(288)=-1.321, p>.05]$ boyutuna yönelik ortalamalarda ise kontenjanı doldurma değişkenine göre anlamlı bir fark görülmemiştir.

\section{Sonuç ve Tartışma}

12 farklı BÖTE bölümüne kayıtlı 290 hazırlık ve 1. sınıf öğrencisi ile yürütülen bu araştırmada erişilen sonuçlar aşağıda özetlenmiş ve tartışılmıştır.

Öğrencilerin yerleştikleri BÖTE bölümünden en çok YÖK Atlas, ÖSYS tercih kılavuzu, aileleri ve bölüm web sitesi aracılığı ile haberdar oldukları belirlenmiştir. Ayrıca, öğrencilerin \% 67.6'sı, tercihlerini yaparken yerleştikleri BÖTE bölümünün web sitesini ziyaret ettiklerini belirtmişlerdir. Ülkemizde yapılan araştırmalara göre; öğrencilerin tercih listelerinde hangi bölümlere yer verecekleri konusunda akıl danıştıkları kanallar arasında sınıf ve ders öğretmenleri, ÖSYM kaynakları, meslekler rehberi kitapları (Özyürek ve Kılıç-Atıcı, 1993), anne-baba (Özyürek ve Kılıç-Atıc1, 1993; Sarıkaya ve Khorshid, 2009) ve ilgili meslekte çalışan akrabalar (Sarıkaya ve Khorshid, 2009) bulunmaktadır. Ancak Gezgin (2015) yaptığı çalışmada farklı şekilde, dershane ve lise öğretmeninin etkisi olmadığını bulgulamıştır. Buna dayalı olarak, üniversitelerin ve bölümlerin web sayfalarının da ögrencilerin bireysel araştırmaları için doyurucu bilgiler sunmasının karar vermeyi etkileyecek bir faktör olacağı düşünülebilir. $\mathrm{Bu}$ web sayfaları aynı zamanda, kurumun algılanan değerini belirleyen faktörlerin aday öğrencilerce görülür hale getirilmesi açısından elverişli bir ortam olarak değerlendirilebilir.

Üniversitenin özelliklerinden, üniversitenin namı öğrencilerin tercihlerini etkileyen en baskın boyut olarak ortaya çıkmıştır. Üniversitenin özelliklerinden üniversitenin konumu ve bölüme ilişkin özelliklerden bölümün niteliği öğrencilerin tercihlerinde onları etkileyen diğer iki boyut olarak öne çıkmaktadır. Kontenjanını dolduran dört bölüm ile doldurmayan diğer bölümlerin öğrencilerinin tercihleri karşılaştırılarak analiz edildiğinde; Üniversitenin olanakları ve Bölümün niteliği boyutları, kontenjanını tam dolduran üniversitelerdeki öğrencilerin tercihlerini, kontenjanını doldurmayan BÖTE'lerdeki öğrencilere kıyasla istatistiksel olarak anlamlı derecede daha fazla etkilemiştir. Üniversitenin kопити boyutu, kontenjanını doldurmayan üniversitelerdeki öğrencilerin tercihlerini kontenjanını dolduran BÖTE'lerdeki öğrencilere kıyasla anlamlı derecede daha fazla etkilemiştir.

Sonuç olarak; BÖTE’yi tercih eden 2017 girişli tüm öğrencilerin tercihlerinde, üniversitenin namı ve konumu en etkili boyutlar olarak öne çıkmıştır. Akar'ın (2017) iktisadi ve idari bilimler fakültesi öğrencileriyle yaptığ çalışmada üniversite tercihinde en çok akademik saygınlık, üniversitenin coğrafi konumu ve üniversiteyle ilgili bilgi edinilen kaynaklar faktörlerinin dikkate alındığı belirtilmiştir. Bu çalışmada benzer sonuçların ortaya konduğu söylenebilir. Bu bulgu, bölümün niteliğinin üniversitenin niteliğinden ayrı bir etkiye sahip olamayacağı ve üniversitelere bir bütün olarak bakılmasının önemli olduğunu düşündürmektedir.

Ayrıca, Bölümün niteliğinin de BÖTE öğrenci tercihlerini etkileyen önemli bir faktör olduğu görülmüştür. Bunun özellikle; Üniversitenin sunduğu olanakları tercih nedeni olarak belirten öğrencilerin aksine, kontenjanını dolduran BÖTE bölümü öğrencilerinin lehine olması da ayrıca dikkate alınması gereken bir sonuç olarak görülmelidir. Sosyal medya ile haberlerin, bilgilerin hızla yayıldığı bir dünyada, bölüm olarak başarılarınızın yayılmaması mümkün değildir. BÖTE 1. sınıf öğrencileri Bölümün niteliği boyutu altında yer alan Aldı̆̆ım duyumlara göre bu BÖTE bölümünün eğitim kalitesinin yüksek olması ve Bu BÖTE bölümü mezunlarının iyi yerlerde iş bulması maddelerine yüksek değerlerle katılım göstermiş olmaları bunun bir göstergesi olabilir.

Araştırma sonuçlarının BÖTE bölümlerine; hedef kitlelerini daha yakından tanıma, bölümün niteliğini artırıcı yeni stratejiler üretme ve bölümün niteliğinin üniversitenin niteliği ile birlikte algılandığı gerçeğini göz önünde tutarak hareket etme açılarından yarar sağlayacağı umulmaktadır. 


\section{Kaynakça/References}

Akar, C. (2012). Üniversite Seçimini Etkileyen Faktörler: İktisadi Ve İdari Bilimler Öğrencileri Üzerine Bir Çalışma. Eskişehir Osmangazi Üniversitesi İ̈BF Dergisi, 7(1), 97-120.

Büyüköztürk, Ş. (2006). Veri Analizi El Kitabı (6. Baskı). Ankara: Pegem Yayıncılık

Germeijs, V. \& Verschueren, K. (2006). High school students' career decision-making process: A longitudinal study of one choice. Journal of Vocational Behavior, 68(2), 189-204.

Gezgin, D. M. (2015). Bilgisayar ve öğretim teknolojileri eğitimi bölümünde öğrenim gören öğrencilerin bölümlerini seçme nedenlerinin incelenmesi: Trakya üniversitesi örneği. Trakya Üniversitesi Sosyal Bilimler Dergisi, 17(2), 297-311.

Korkut-Owen, F., Kepir, D. D., Özdemir, S., Ulaş, Ö. ve Yılmaz, O. (2012). Üniversite öğrencilerinin bölüm seçme nedenleri. Mersin Üniversitesi Ĕ̈itim Fakültesi Dergisi, 8(3), 135-151.

Pallant, J. (2013). SPSS Survival Manual. UK: McGraw-Hill Education.

Sarıkaya, T., ve Khorshid, L. (2009). Üniversite öğrencilerinin meslek seçimini etkileyen etmenlerin incelenmesi: Üniversite öğrencilerinin meslek seçimi. Türk Eğitim Bilimleri Dergisi, 7(2), 393-423.

Özsoy, G., Özsoy, S., Özkara, Y. ve Memiş, A. D. (2010). Öğretmen adaylarının öğretmenlik mesleğini tercih etmelerinde etkili olan faktörler. İlköğretim Online, 9(3), 910-921.

Özyürek, R. ve Kılıç-Atıcı, M. (1993). Üniversite öğrencilerinin meslek seçimi kararlarında kendilerine yardım eden kaynakların belirlenmesi. Türk Psikolojik Danışma ve Rehberlik Dergisi, 2(17), 33-42.

ÖSYM. (2017). 2017-ÖSYS Yükseköğretim Programları ve Kontenjanları Kllavuzu - Tablo 4. Türkiye Cumhuriyeti Ölçme, Seçme Ve Yerleştirme Merkezi Başkanlığı. http://www.osym.gov.tr/TR,13263/2017-osysyuksekogretim-programlari-ve-kontenjanlari-kilavuzu.html adresinden elde edildi.

Roblyer, M. D. (2006). Integrating educational technology into teaching. Pearson Education Inc.

The National Research Center for College \& University Admissions (NRCCUA). (2014, 1). What Drives Students' Enrollment Decisions? http://www.eduventures.com/2014/04/drives-students-enrollment-decisions/ adresinden elde edildi.

YÖK. (2017). Yükseköğretim Program Atlası, Bilgisayar ve Öğretim Teknolojileri Öğretmenliği Programı Bulunan Tüm Üniversiteler. https://yokatlas.yok.gov.tr/lisans-bolum.php?b=20101 adresinden elde edildi. 